\title{
KÖZPONTI FUNKCIÓK FELTÁRÁSA VAS MEGYÉBEN
}

\author{
(Exploring central functions in Vas county) \\ LENNER TIBOR
}

\section{Vas megye településhierarchiája}

A településeknek a településhálózatban elfoglalt helyưk és funkcióik alapján kialakul térbeli rendjük, hierarchiájuk. Viszont maga a településhierarchia soha nem jelent egy stabil állapotot, a politikai, a társadalmi, gazdasági változások, folyamatok hatással vannak rá, alakítják. Tehát amikor egy térség településhálózatát, annak térbeli rendjét elemezzük soha nem feledkezhetünk meg arról, hogy ez a folyamatnak egy állapota az adott időmetszetben.

Az államszocializmus időszakában a centralizációra törekvő politika a hiẻrarchia erőltetett szintjeit állította fel. Bár az 1971. évi Országos Településfejlesztési Koncepciót (OTK) számos vonzáskörzetekre és a települések központi szerepkörére vonatkozó vizsgálat elözte meg, mégis bevezetésének sikertelenségére utal, hogy hamarosan megindult a vita a módosításának szükségességéröl, s 1981-ben ez meg is történt.

A rendszerváltás után az önkormányzati törvény a településhálózat atomizációjának irányába hatott, széttörte a korábbi adminisztratív szerveződéseket. Így alakulhatott meg országosan a 3200 települési önkormányzat, (Vas megyében 216), azaz ahány település, annyi önkormányzat.

Ésszerủ, alulról építkező, a partnerkapcsolatokat kereső újraszerveződés elkerülhetetlen, de hogy ez ne eröszakolt legyen, ahhoz ismerni kell a telepúléshálózatban lezajló folyamatokat. A csupán vázlatos, egymásnak ellentmondó hipotéziseken alapuló erőltetett településhierarchia kialakítása tévesnek bizonyuló döntésekhez vezetett (Beluszky 1973), s vezethet ma is.

Ezért fontos a településhierarchia dinamikájạ́t folyamatában feltárni, részletesen elemezni, hogy megszülethessen a településhierarchia objektív feltárása és értékelése, mely a fejlesztési stratégiákat megalapozhatja.

A településhálózat kialakulásának hosszú folyamatát az ország más területeihez képest kevésbé zavarta meg a trianoni döntés Vas megyében. A második világháború után "felhúzott" vasfüggöny hatása erösebb volt, hiszen a határon túl nyúló kapcsolatok évtizedekig nem létezhettek, a régebbiek megszüntek, újak nem születhettek. Ez egy határmenti megye térszerkezetében, településhálózatában maradandó sebeket eredményezett.

E sebhelyekkel együtt a megye településhálózata az évszázados fejlődés eredménye, melyet az utolsó 50 év - az utolsó 5 év különösen - és a jelen is folyamatosan formál.

Vas megye településszerkezete alapvetỏen aprófalvas szerkezetủ. A megye településeinek 92,6\%-a 2000 fönél kevesebbet számlál, és ezekben él az összlakosság $36,9 \%$-a. Az átlagnépesség városokkal együtt is csak 1295 fö, míg ugyanez az adat az országban 3485 fö. A legkisebb faluban, Nemesmedvesen 23-an élnek, a legnagyobb népessége a megyeszékhelynek, Szombathelynek van: 85932 fö (1993). 
Hazánkban a településnagyság szoros összefüggésben van a fejlettséggel, az aprófalvak komoly gondokkal küszködnek. Nem vagy csak nehezen tudnak megfelelni alapellátási közszolgálati funkcióiknak, és elmaradottságuk még inkább szembeötlö, ha centrumhiányos térségben fekszenek.

A települések területének nagyság szerinti megoszlását figyelve a falvak közül szigetszerủen emelkednek ki a városok területei (min.: 293 ha, max.: 9752 ha). Az átlagos területnagyság 1595,64 ha, ez azt jelenti, hogy a megyében magas a településsürüség értéke: $100 \mathrm{~km}^{2}$-re 62,7 település jut.

A városok nagyság szerinti hierarchiájában megyeszékhely után a kisvárosok következnek. Általánosan elfogadott nézet, hogy az abszolút méret alapján a 10 ezer és 30 ezer közötti lakosságszámú, városi jogállással bíró településeket tekintik kisvárosoknak. Sárvár lakossága 15626 fö, Körmendé 12528 fö, Köszegé 12137, Celldömölké 11851, Szentgotthárdé 8662, míg Vasvárnak csak 4773, Csepregnek 3949 lakosa van.

Ezek az adatok ráirányítják a figyelmet a várossá válás folyamatára a megyében. Vas megye urbanizációs fejlődésére helyi és országos folyamatok egyaránt hatással voltak. A II. világháború után nyugati hatórmenti fekvése miatt hátrányos helyzetbe került, periférikus helyzete felerösödött. Nem történtek komolyabb ipari beruházások, hagyományos kereskedelmi kapcsolatai elsorvadtak, aminek következtében a népességszám csökkent, megindult az elvándorlás, és stagnált a városok fejlödése is.

Szombathely és Kőszeg mellett 1970 -ig csak Sárvár nyerte vissza városi rangját. A változó politikai megítélés, óvatos gazdasági nyitás miatt aztán a megye kedvezöbb helyzetbe került a területi munkamegosztásban, amelynek hasznát elsősorban a városok kamatoztatták: 1970 és 1985 között ủjabb három település, Celldömölk, Körmend, Szentgotthárd kapta vissza városi címét az OTK tudatos kisváros-fejlesztési programjának megfelelöen. A sort 1986-ban a funkcióhiányos központként várossá vált Vasvár zárta. Jórészt viszont az is az OTK-nak köszönhetö, hogy a falvak többsége nem tudta megörizni meglévő funkcióit, felgyorsult az aprółalvak népesség-eróziója, tovább erősítve ezzel a már meglévő regionális különbségeket.

A városok vonzáskörzete meglehetősen kiterjedt, ugyanakkor a vonzáskörzeti határok mentén elhelyezkedö települések érzik periférikus helyzetüket. A városok vonzása lecsökken, mert ellátási körzetük kiterjedéséhez képest központi funkcióik fejletlenek, ez alól csak Szombathely kivétel. Így a városok funkcióinak erősitése mellett más települések centrumként való fejlesztése is felmerült: Bük, Csepreg, Jánosháza, Öriszentpéter és Répcelak térbeli helyzete a legkedvezöbb a várossá válásra. A felsoroltak közül Csepreg 1995. július 1-jén kapta meg a városi címet. (Csapó 1994.)

Vas megye településeinek száma ma 216. Az utóbbi 5 évben 3 szétválás történt, részben a várossá nyilvánítások következményeként. 1993. január 1-jén vált ki Alsóújlak község Vasvárból. Az 1986-os egyesítésig társközsége volt a vasvári közös tanácsnak, azaz önálló község volt. A várossá nyilvánításkor két lehetőség kínálkozott: vagy önálló falu, vagy Vasvár város része lesz. Az addigi várossá nyilvánítási gyakorlatot követve az utóbbi elképzelés valósult meg. A település polgárai az egyesítés után azonban kisemmizve érezték magukat, ezért végig harcoltak az önállóságért, ez a folyamat 1989-90-ben gyorsult fel.

Csepregből Tormásliget 1993. július 1-jén vált ki. Utóbbi korábban külterületi lakóhely, uradalom volt, azaz soha sem volt önálló község. Bár formailag megfelel községi funkcióinak, racionálisan, államigazgatási szempontból megkérdőjelezhető önállósága. 
Vas megyében történt egy harmadik szétválás is, ez azonban az előző kettőtől eltérő típust képvisel. Sömjénmihályfa esetében ugyanis két falu, Kemenessömjén és Kemenesmihályfa vált ketté 1993. január 1-jén. A történelmi elózményekhez tartozik, hogy 1938 és 1946. január 1. között már egyszer egységes volt Sömjónmihályfa. Utána azonban mesterségesen szétválasztották, mert az önálló tanácsok élére olyan kádereket neveztek ki, akiket könnyebben tudtak felülről ellenőrizni, irányítani. A két község 1982. január 1-jén egyesült újra, majd 1993-ban újra szétváltak. Emögött az a politikai akarat áltt, hogy a régi tanácsi vezetést mindenképpen meg akarták buktatni a faluban, ha kell, szétválással is. Az osztozkodáskor Kemenesmihályfára került az iskola, az óvoda, a régi „közös” - polgármesteri hivatal, míg Kemenessömjén kapta az orvosi rendelót és a kultúrházat. A következmény az lett, hogy aprófalvas települések lettek, így kevesebb pénzböl gazdálkodhatnak, ráadásul többe kerül az államigazgatás, gazdaságilag tehát egyértelmüen veszített mindkét falu.

Kemenessồmjén 13 millió forintos éves költségvetéséből pl. 4 millió forint megy Kemenesmihályfára, az ott tanuló sömjéni gyerekek normatív támogatására. Kemenesmihályfa viszont az orvosi rendelő fenntartásához járul hozzá. Beruházásaikat, programjaikat is csak közös összefogással tudják végrehajtani: most pl. együtt vezetik a gázt, mindkét falu használja a kultúrházat, közösek az iskolai ünnepségek.

Összefoglalva a szétválások okait, azok közül kettő mindenképpen kiemelendő:

- rơvid távú politikai érdekek, okok (a 2 millió forintos kvóta megszerzése, a „régi” tanácselnök-polgármester megbuktatása)

- „,sérelmek” orvoslása: a kisemmizettség érzésének politikai megnyilvánulása.

\section{Központi szerepkörök a nem városi jogkörü településekben}

Egy aprófalvas textúrájú, elmaradott településekböl, kistérségekböl álló régióban különösen fontos azt megvizsgálni, hogy a megye térszerkezetében a sokszor hiányos intézményi ellátottságú városok mellett mely települések rendelkeznek központi funkciókkal. E települések szerepkörükkel képesek-e a más városok alttal le nem fedett térben a keletkezett ürt pótolni, bizonyos szerepköröket átvállalni?

A központi funkciók feltárásához a következő intézmények, társulások meglétét vagy hiányát vizsgáltuk: körjegyzöségi központokat, az épitésügyi hatósági központokat, a csatornamú társulatokat. ${ }^{1}$

Figyelembe vettük továbbá a felnőtt háziorvosi körzetek központjai, az általános iskolai központokat, a hatósági állatorvosi központokat és a gazdajegyzöi körzetek központjait.

$\mathrm{Az}$ adatokat egyrészt a megyei igazgatási szervektől sikerült beszerezni (Köztársasági Hivatal, Nyugat-dunántúli Vízügyi Igazgatóság, Pedagógiai Intézet, ÁNTSZ, Agrárkamara), másrészt e meglévő adatbázist bővítették azok a kérdőivek, amelyeket az egyes önkormányzatok vezetöi töltöttek ki.

A központi funkciók vizsgálatához 4 csoportot alakítottunk ki:

I. csoport: központképzỏ funkcióval nem rendelkezö települések;

II. csoport: 1-2 központképzỏ funkcióval rendelkezök csoportja;

III. csoport: 3-4 központképző funkcióval rendelkezök csoportja;

IV. csoport: 5, vagy ennél több központképző szereppel rendelkezö települések csoportja. 
A Vas megyei települések központi funkciók szerinti csoportosítását mutatja az 1. ábra. A legnépesebb kategória a központi funkcióval nem rendelkezőké, ide a települések $60 \%$ a, szám szerint 131 település tartozik. A második csoportba sorolódott 43 község, az összes település $20 \%$-a. A harmadikba 25 település, azaz 12\% tartozik, a negyedik csoport értékeit pedig 17 település, azaz 8\% érte el. Az utóbbi körbe sorolódtak természetszerủen a kisvárosok és a megyeszékhely is, Vasvárt kivéve, amely a harmadik kategóriában foglal helyet.

Nemcsak az alapellátottság mértéke és a települések nagysága között van szoros összefüggés, hanem a több településre kiterjedö központi funkciók száma és az átlagos lélekszám között is. A központi funkcióval nem rendelkezỏ települések átlagos lélekszáma 379, a 131 ide tartozó községből csak négy község lélekszáma haladja meg az 1000 föt. E kategóriába tehát túlnyomórészt az aprófalvak kerültek. A központi funkciók számának emelkedésével az átlagos lélekszám is nő: a 2. kategóriában 751, a harmadikban 882, a negyedikben a városokkal együtt 9928 , városok nélkül pedig 1810 fö.

Ha a 4. csoportot a városok nélkủl vizsgáljuk, látható, hogy a 10 településből 5 - Torony, Gencsapáti, Söpte, Vép, Vasszécsény - a Szombathelyt övezö gyürüben helyezkedik el, számukra tehát a megyeszékhely-közeliség jelentett elönyt a több településre kiterjedő funkciók megszerzésében és működtetésében, tehermentesítve ezzel a várost. Feltünő az is, hogy a megye elmaradott térségének számító D-i, aprófalvas régióhoz csak Jánosháza, Györvár és Öriszentpéter tartozik, illetve a városok közül Szentgotthárd. Igaz viszont, hogy a „középmezönyhöz” tartozó, 3-4 központi szereppel rendelkező 25 település közül az elmaradott térségben 11 található, azaz a csoport 44\%-a, köztük a városi ranggal bíró Vasvár. E települések valamit enyhítenek az egyetlen nagyobb centrum vonzásába sem eső aprófalvak gondjain, hiszen többségük körjegyzöséggel, körzeti orvossal, körzetesített általános iskolával és állatorvossal rendelkezik. Igaz az is, hogy gazdasági, igazgatási erejük ahhoz már nem elegendö, hogy maradéktalanul lefedjék a városok által üresen hagyott teret.

Az egyaránt 5-5 központi funkcióval rendelkező Bỏ és Répcelak számára a megye É-i határán pedig az jelent előnyt, hogy fontos útvonalak közelében helyezkednek el, közlekedés-földrajzi helyzetük, tehát kedvezỏ.

Az 1-2 központi funkcióval rendelkező községek szóródása egyenletes, bár az elmaradott térség itt is rosszabb mutatókkal rendelkezik, míg a megye településeinek $35 \%$ a tartozik ide, addig a térséghez a 2 . csoportból csak a megye településeinek $9 \%$-a sorolódik.

Összegzésképpen megállapíthatjuk, hogy a társulások központjai ma is a nagyobb településekben találhatók, de az 1-2 központi funkció jelenléte még nem jelent központi szerepkört a település számára, ugyanakkor azok a települések, melyekben 4-5 funkció jelen van, már rendelkeznek térségszervezó erövel. Ezek azok a települések, melyek alapellátottságuk alapján már elemi centrumként viselkednek, külön csoportot alkotnak. Ezek közvetlenül a városok alatti hierarchiaszinten helyezkednek el. Centrum szereppel föleg azok birnak, melyek az elmaradott térségekben a perifériákon találhatók (Öriszentpéter, Jánosháza, Répcelak), s nem Szombathely agglomerációjában (Torony, Vép, Söpte). 


\section{1. ÁBRA}

Központképzö funkciok Vas megyében

(Seetlements with central functions in Vas county)

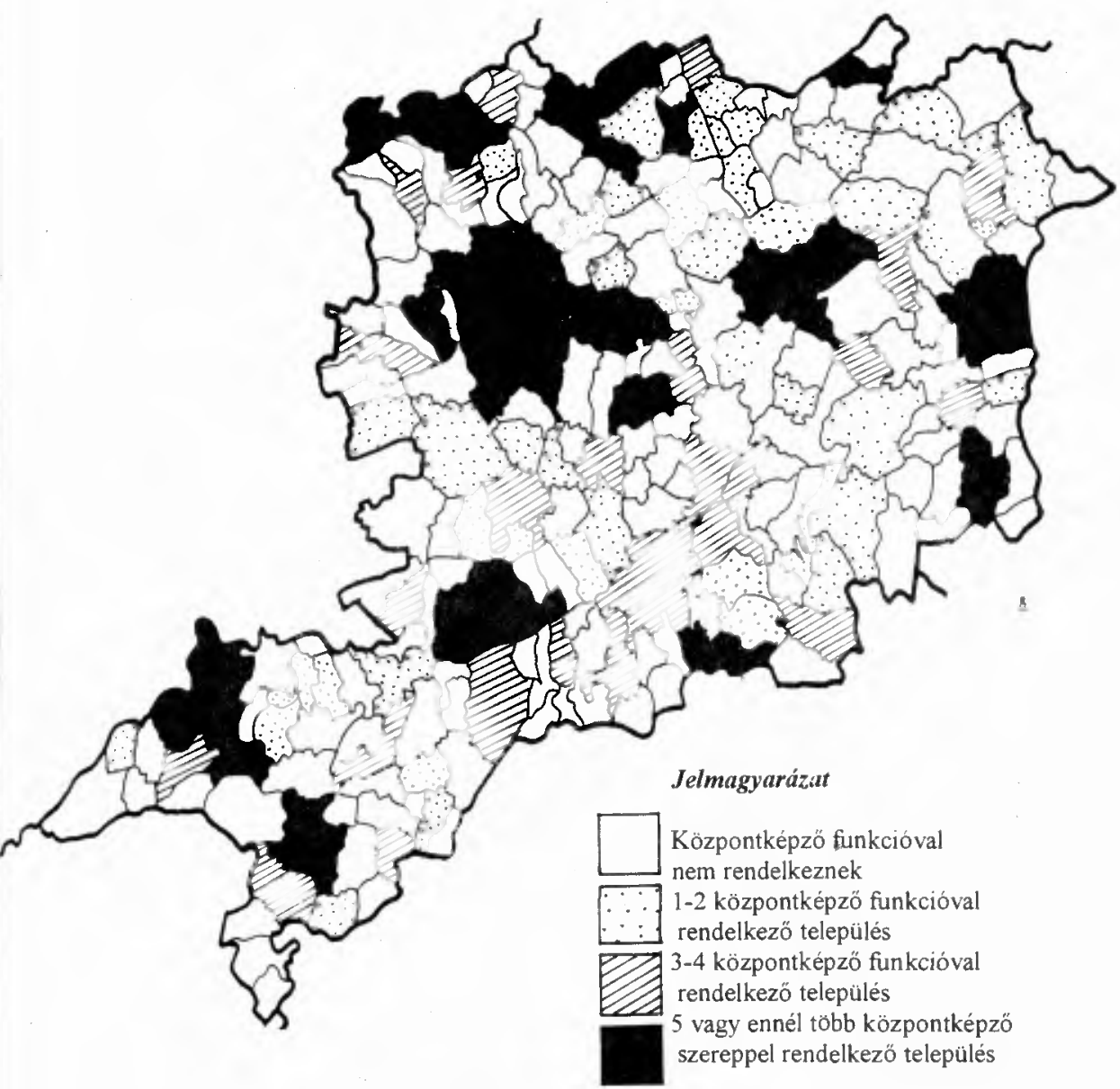




\section{A kisvárosok középfokủ intézményi és infrastrukturális ellátottságának mérése}

A központi funkciók olyan magasabb szintü szerepkörök, melyek a nem mindennapos szükségletek megfelelő minőségi szinvonalon történő kielégítésére szolgálnak. Az ezeket a feladatköröket megszerző, müködtető, és ezzel a környékük településeire vonzást gyakorló településeket városoknak nevezzük. A kisvárosok pedig azok a 10000 és 30000 közötti lakossal rendelkező városi jogállással bíró települések, amelyek társadalmuk megítélésében emberi léptékúek, könnyen áttekinthetők, keretét adják a helyi politika érvényesülésének, napi érintkezésben állnak vidékükkel, a falvakkal és nagyobb városokkal. (Lenner 1995)

A várossal szemben támasztott igények szerint megkülönböztetünk primer, szekunder és tercier funkciókat. E funkciók adják a kereteit az újdonságok fogadásának, a városi térbe való beépülésének. Emellett a gazdasági - piaci tényezők, az infrastrukturális felszereltség, a társadalmi- történelmi-kulturális hagyományok mind-mind hozzájárulnak az újdonságok megtelepedéséhez. A településrendszerbe való illeszkedésnél azonban súlyos válság jelei mutatkoznak a kisvárosoknál: egyrészt sokuk gazdasága követő jellegủ, válságágazatokat tömörítő, másrészt sem müszaki, sem szellemi hátterük nem készült fel az újdonságok fogadására, adaptálására.

Az oktatási igények kielégítésére szolgáló középiskola valamennyi vasi városban van, általában kettő, Csepreget és Vasvárt kivéve, ahol egy, és Szombathelyt, ahol tizenhárom található. A középfokú oktatási szerepkört tekintve kimagasló a köszegi gimnázium szerepe, ahová a magas szintü idegennyelvi képzés miatt az egész megyéböl iskoláznak be fiatalokat, így Szombathely után Köszegen a legmagasabb a középiskolai tanulók száma. Az 1000 lakosra jutó középiskolai tanulók száma Szombathelyen a legmagasabb $(81,5)$, utána Köszeg következik $(68,4)$, míg a többi kisváros ennél lényegesen kisebb értéket ért el (26-56 között).

Felsőfokú tanintézetei csak a megyeszékhelynek vannak, ahol a nappali tagozaton tanulók száma közel 2500, az oktatók száma 274, és ezekkel az értékekkel Szombathely a nyugat-dunántúli régióban Győr után a legnagyobb felsőoktatási centrumnak számít. Ezek az intézmények olyan szellemi alkotó mủhelyek, ahol kutatómunkát is végeznek, és ezért hatásuk nemcsak a megyére, régióra, hanem az országra is kisugárzik. Ezek inspiráló hatására csak egy példa: Szombathelyen, ahol a tanárképzỏ föiskola, az egészségưgyi föiskola és a megyei kórház múködik, az 1980-as évtized végén hárman rendelkeztek a tudomány doktora fokozattal, és 32-en voltak a tudomány kandidátusai. (Gảl 1988) A megye többi kisvárosában tudományos minősített oktató, kutató nem él, azaz e településkörben csaknem teljesen hiányzik a tudományos alkotótevékenység, a meglévó pedig nem jelent többet elszigetelt, esetlegesen jelentkezö, egyéni kezdeményezésnél.

A felsőfokú végzettséggel rendelkezők aránya a 7 éves és idősebb népességböl az országos átlagértékhez közeli. Az átlagértéktöl jelentös eltérést Szombathely $(10,78 \%)$ és Vasvár (4,81\%) mutat. E két - legmagasabb és legalacsonyabb - érték közti eltérés több, mint kétszeres, ami kb. hasonló a régió többi megyéjének adataihoz, és fele az országos eltérésnek (utóbbi több, mint négyszeres). Az aktív keresőkhöz viszonyítva a legtöbb felsőfokú végzettségü Szombathely mellett Köszegen, Körmenden, Sárváron él, ezek a városok 10\%-on felüli értékeket értek el. 
A középfokủ iskolázottsági szint az aktív keresők körében Csepreget kivéve mindenhol $50 \%$ feletti, a 7 éves és idősebb népességre vetítve pedig 32\% körüli, amitöl ismét Csepreg marad el (25,9\%). A 20-24 éves korosztályhoz viszonyított felsőfokú hallgatók aránya nagyobb szóródást mutat, itt Szombathely külön kategóriába tartozik $(23,18 \%)$ mellette Körmend, Celldömölk, Sárvár, Köszeg alkot egy csoportot 5\% körüli mutatóval, míg Vasvár, Szentgotthárd, Csepreg $2 \%$ alatti értékeivel leszakad a többi várostól.

A 8 városból ötnek van kórháza, Csepregnek, Köszegnek, Vasvárnak nincs. Az intézmények közül a legnagyobb a szombathelyi megyei kórház 1670 ággyal, amely regionális feladatokat is ellát. A többi városnak kiskórháza van 120-160 ággyal vonzáskörzetre kiterjedő szereppel-, de az önkormányzatok számára súlyosan forráshiányos anyagi helyzetükben még ezek fenntartása is gondot jelent. Felmerult több kórház leépítése és/vagy megszüntetése is a megyében, amely ellen a helyi lakosság elkeseredetten tiltakozott. Átmeneti megoldásnak az látszott, hogy Celldömölk, Körmend és Sárvár önkormányzata csatlakozna a Rolicare nevú, kórházakat müködtető közhasznú társasághoz. A kezdeményezés mára elhalt.

$\mathrm{Az}$ egészségügyben és a kulturális szférában dolgozók részesedése az összes aktív keresőböl Vasvárt kivéve mindenhol $10 \%$ feletti, amely megfelelő szellemi hátteret biztosít a kisvárosok fejlódésének. Kiugróan magas Köszeg 20,4\%-os adata, amellyel Szombathelyt $(16,2 \%)$ is megelözi, és a régió olyan városainak társaságában található, mint Sopron, Balatonfüred, Hévíz, Keszthely.

A szellemi erőforrások mellett a gazdasági aktivitásnak, az új, már piaci viszonyok között létrejövő és müködő szervezeteknek is hatása van a környező településekre. A magánvállalkozások számszerü adatai arról vallanak, mennyire rugalmas a szervezeti formák szintjén a helyi gazdaság. Vas megye kisvárosai az ÉNy-Dunántúlon az utolsó helyen állnak. Az 1000 före jutó magánvállalkozások száma a megyében Szombathely után Sárváron a legmagasabb (78,77 illetve 71,55), a további sorrend Vasvár, Celldömölk, Körmend, Szentgotthárd, Kőszeg, Csepreg, 50 köruli értékekkel. A megye tehát még mindig nem tudta kiheverni a múlt területpolitikájảnak káros hatását, azt, hogy a nyugati fekvéséböl, polgári hagyományaiból fakadóan kimaradt az iparosításból, és az ezzel együtt járó infrastruktúra fejlesztésből. Ugyanakkor a nyugati országhatár menti városokban várható, hogy a magángazdaság erős kapcsolatokat épít ki Ausztria és Szlovénia felé. A határok megnyíltával a gazdasági térben helyzetük kedvezően változik, de a magángazdaság valódi súlya, tőkeereje, hatékonysága számszerủ adatokkal még nehezen mérhetö.

Ingatlan-ügynökség csak két városban müködik (Szombathelyen 5, Sárváron 1), míg összehasonlításul a szomszédos Veszprém megyében, ahol az idegenforgalom szerepe jóval nagyobb, 5 városban összesen 12 ingatlanügynökség van.

Kevés az ügyvédek száma is: 92 dolgozik a megyében. Ez a Györ-Moson-Sopron megyei értéknek a fele, a Veszprém megyeinek kétharmada csak. Ráadásul a Vas megyei ügyvédek $80 \%$-a Szombathelyen müködik, ez a koncentráltság az említett két megyében kisebb, $60 \%$ körüli.

A Legfelsöbb Bíróság által bejegyzett egyesületek számából lehet következtetni a társadalmi aktivitásra, de a megyeszékhely mögött a kisvárosok ezen a téren is lemaradnak: amig Szombathelyen 416 egyesület müködik, addig a 7 városban összesen csak 293. Sárváron jegyezték be a legtöbb egyesületet (72), míg Csepregen a legkevesebbet (14). 
Korlátozottak a hirdetési lehetőségek is, jószerivel csak Szombathelyen lehet válogatni a lehetőségek közül, a régió többi kisvárosában - a Vas megyeiekkel szemben - viszont már ezen a téren is nagyobb az aktivitás.

Az elemzett adatok arra mutatnak, hogy Vas megye kisvárosai, mint vonzásközpontok csak ellentmondásosan tudnak megfelelni a központi szerepkörböl adódó követelményeknek. Szinte azt mondhatjuk, hogy a kisvárosoknak a várossá válás időrendjével egyenesen arányos a városi hierarchiában elfoglalt helyük, azaz minél fiatalabbak, annál lejjebb helyezkednek el. Vasvárra és Csepregre ez teljes mértékben igaz, funkcióik még meglehetősen hiányosak.

\section{Jegyzetek}

1 A vízmú társulatok mára már megszűntek, vagy megszünőben vannak, hiszen a vízellátás megyeszerte megoldott. Mivel a társulatok meghatározott feladatra jöttek létre, a beruházás megkezdésétỏl számitott 10 éven belül feloszlanak.) Itt kell megjegyezni azt is, hogy a gáz társulásokról az ÉGÁZ Rt. az energiaszektor privatizáció elötti állapota miatt adatokat nem szolgáltatott. A gáz vezetéskor azonban nem különbözö önkormányzatok társulnak, hanem minden önkormányzat maga alakít gáztársulást.

\section{Irodalom}

Beluszky P. (1973) A településosztályozás néhány elvi módszertani szempontja. Földrajzi Értesítö 4. 453-466. 0 .

Csapó T. (szerk.) (1994) Térségi folyamatok a Nyugat-Dunántúlon. Kézirat, MTA RKK ÉDO Vas megyei Kutatócsoport, Szombathely, 57. o.

Gál V. (1988) Tudományos fokozatú szakemberek Vas megyében. Vasi Szemle XLII. évf. 4. sz.

Lenner T. (1995) Az értelmiség szerepe a kisvárosok modernizációjában Celldőoơlk és Sárvár példáján. Földrajzi Ertesitö, 3-4. 245-258. 0.

\section{Abstract}

The development of urbanisation in Vas county was influenced by both local and national processes. Following World War II, the county found itself in an unfavourable situation because of its location along the western border, thus its peripheral situation further worsened. Significant industrial investments neglected this county, its traditional trading connections vanished, consequently its population decreased, outmigration started and the development of the towns stagnated, too.

The analysed data reveal that fact that the small towns as the attraction centres in Vas county could only meet the criteria of the central role with contradictions. We can practically say that there is a direct proportion in the chronology of the towns obtaining this status and their places in the urban hierarchy, i.e. the younger they are the lower they can be found in the hierarchy. It is absolutely the case with Vasvár and Csepreg, their functions are still rather deficient. 